\title{
Urban Agriculture in Latin America: A Green Culture Beyond Growing and Feeding
}

\author{
Fabiana Castellarini* \\ Instituto Argentino de Investigaciones de Zonas Áridas, Centro Científico Tecnológico CONICET, Mendoza, Argentina
}

Over the coming decades, the level of urbanization in Latin America (LA) is expected to increase nearly $90 \%$, with unwanted consequences such as accentuated socio-economic inequalities, food insecurity, violence, and environmental and health crises. In LA countries, urban agriculture (UA) has been adopted as one of the major strategies to address urban poverty and food insecurity, which have increased for different drivers, such as population growth, economic crises, or forced migration. Nevertheless, experience in these countries has demonstrated that urban agriculture is a complex activity that involves multiple benefits, risks, actors, processes, scales, and interactions. In this review, I analyse urban agriculture in LA countries using the ecosystems services framework as a tool to integrate UA functionalities and the four

OPEN ACCESS

Edited by:

Cynnamon Dobbs, Universidad Mayor, Chile

Reviewed by:

Tenley M. Conway, University of Toronto

Mississauga, Canada Lorenzo De Vidovich, University of Trieste, Italy

${ }^{*}$ Correspondence:

Fabiana Castellarini terraspot4@gmail.com

Specialty section: This article was submitted to Urban Greening, a section of the journal Frontiers in Sustainable Cities

Received: 10 October 2021 Accepted: 28 December 2021

Published: 17 February 2022

Citation:

Castellarini $F$ (2022) Urban Agriculture in Latin America: A Green Culture Beyond Growing and Feeding. Front. Sustain. Cities 3:792616. doi: 10.3389/frsc.2021.792616 sustainability dimensions. I considered five issues derived from plant production: (1) ecosystem services, benefits, assets, drivers, and stakeholders in UA; (2) ecosystem services bundles; (3) economic and socio-cultural factors associated with the ecosystem services bundles; (4) research progress in LA countries; (5) issues and possible strategic directions in decision-making of UA in the LA region. Using proxy variables, a total of 17 ecosystem services, six benefits, six assets, and six indirect drivers were recognized. Projections of the 17 variables over the four dimensions of sustainable development showed that the environmental dimension was most studied than the social, economic, and governance dimensions. Most of strengths of $U A$ in LA were related to ecosystem services, benefits, and beneficiaries; main weaknesses were related to the misuse of inputs, and human and environmental health; threats were related to regulation, governance and land tenure issues, and opportunities to several topics related to the four dimensions of sustainability. The concepts, frameworks, and methods used in this study may be effective tools to make scientific information available to managers and decision makers.

Keywords: urban agriculture, Global South, ecosystem services, urban greening, poverty, public policies, sustainability

\section{INTRODUCTION}

Urban agriculture (UA) is an activity with a long tradition in the Latin American (LA) region, which, by the end of the twentieth century, exhibited a mix of farming systems shaped by pre-Columbian practices combined with European and Asian models (Smit et al., 2001). Over the past four decades, cities in LA have experienced accelerated population growth rates, and it is 
expected that by 2050 , about $90 \%$ of LA's inhabitants will be living in urban areas (United Nations, 2019). Although cities have traditionally been seen as places for social progress and economic growth, the fast urbanization in LA countries has brought unwanted consequences, such as accentuated socio-economic inequalities, food insecurity, violence, and environmental and health crises (Orsini et al., 2013). Facing these contexts, to achieve greener, healthier, and more equitable cities, global agencies, such as the FAO, RUAF, IDRC, UNDESA, or UN-Habitat/UNDP, urged the inclusion of UA in the public policy agendas (Mougeot, 2005; van Veenhuizen, 2006; Hearn et al., 2020). In line with these appeals and to face crises shaped by regional drivers, such as natural events (e.g., hurricanes and earthquakes), economic crises, political contexts, or forced migration due to armed conflicts, LA's governments, NGOs, private institutions, and civil society organizations consolidated existing UA programs and launched new actions to promote the activity (FAO, 2014).

In a broad sense, UA may be defined as food production in urban areas (Opitz et al., 2016). It implies growing plants and animals for food and other uses within and around cities. It is characteristically an integral part of the urban economic, social, ecological, and governance systems. It uses urban resources, produced for urban citizens; it is strongly influenced by urban conditions and impacts the urban socioecosystem (Mougeot, 2005; van Veenhuizen, 2006).

UA in the LA region, classified as among the developing countries or Global South (GS), has been characterized by a productivist perspective, in which the focus has been on production and on economic growth to solve hunger and poverty in the short term, rather than to deal with the spatial, environmental, social, political, and other economical dynamics on which it is strongly dependent (Orsini et al., 2013; Gray et al., 2020; Follmann et al., 2021). For example, urban farmers may produce foods in their own household, renting private spaces, squatting sleeping lands or in community spaces (SanyéMengual, 2015). UA relies environmental conditions with good water, soil, and air quality to produce healthy products. It may improve access to foods, as well as household incomes by reducing expenses, and may generate employment or income if the production is sold (De Zeeuw et al., 2011). From the household to the final consumers, it can comprise a variety of activities to deliver products for the local market (van Veenhuizen, 2006). Other urban dwellers may participate in the value chain as laborers, producing agricultural inputs (e.g., compost), processing and conserving products, or delivering the products to different parts of the city (Abu Hatab et al., 2019). UA may also become an activity for socially vulnerable groups, such as the elderly, youths, women, people with disabilities, migrants, or people in social rehabilitation (Pudup, 2008; United Nations Development Programme, 2013). It may also generate unwanted effects, such as the pollution of water, soil, or air; health degradation; social conflicts over land tenure; or the emergence of pests and diseases and (Temple and Moustier, 2004; De Bon et al., 2009; Dumat et al., 2019). Therefore, to support, promote, and regulate the UA as an umbrella concept in time and space, all these dimensions need to be taken into account, with citizen participation, research support, legal frameworks, and political willingness.
To better understand the progress of research into the different dimensions and components of UA in LA countries, the aims of this study were (1) to identify urban ecosystem services (UES) derived from UA, with their benefits, drivers, assets, and stakeholders; (2) to identify UES bundles; (3) to identify the economic and sociocultural factors associated with UES bundles; (4) to compare the research progress on UES bundles, benefits, assets, and drivers; (5) to identify issues and possible strategic directions in decision-making on UA in LA countries. Although UA also includes the raising of animals, only the green dimension was considered in this study.

\section{MATERIALS AND METHODS}

\section{Data Collection}

A systematic search and review of the literature was conducted through three complementary electronic search databases, Scopus, Redalyc, and SciELO (Miguel, 2011), from 2000 to April 2021. Dates were chosen in a window of 21 years to search for ecosystem service studies which were mainly promoted from 2001 to 2005 by the Millennium Ecosystem Assessment (MA, 2003, 2005). The search considered articles, reviews, and book chapters published in all sovereign states of LA, both continental and islandic, with Spanish, Portuguese, or French as official languages: Argentina, Bolivia, Brazil, Chile, Colombia, Costa Rica, Cuba, Dominican Republic, Ecuador, El Salvador, Guatemala, Haiti, Honduras, Mexico, Nicaragua, Panama, Paraguay, Peru, Uruguay, and Venezuela. The search was run using a combination of keywords with the name of each country through Boolean operators, e.g., ("urban agriculture" OR "urban farm" OR "urban horticulture") AND "Argentina." The keywords were in English and their equivalent in Spanish and Portuguese.

To extract and organize the information, a combination of concepts and frameworks was used. Ecosystem services provided by UA were identified using the ecosystem service cascade model (Potschin-Young et al., 2018) and the TEEB Manual for Cities Typology (TEEB-The Economics of Ecosystems Biodiversity, 2011). Stakeholders involved in the UA activity were identified, adapting the proposal of Romero-Duque et al. (2020); benefits following the concepts proposed by Daw et al. (2011) and King et al. (2014); and assets and drivers of changes identified using concepts from the MA and IPBES frameworks (MA, 2003, 2005; Díaz et al., 2015). All information was stored in a binary database. Definitions and database structure are shown in Appendix 1.

\section{Data Analysis}

Ecosystem service bundles, defined as a set of ecosystem services that are studied together in the papers reviewed, were identified through a cluster analysis. The distance matrix for binary data was obtained using the algorithm $d=\sqrt{1-S 14}$, with S14 as the phi of the Pearson similarity index (Gower and Legendre, 1986). In the $S 14$ index, $(1,1)$ matches indicate positive associations, $(0,1)$ or $(1,0)$ negative associations, and $(0,0)$ no associations. Ward's linkage was used to build the groups and the kgs function to prune the hierarchical tree. The latter function enables finding the optimal number of clusters to maximize differences between groups and cohesiveness within groups (Kelley et al., 1996). The 
analysis was made using $\mathrm{R}$ functions of the ade4 package (Chessel et al., 2004), maptree package (White and Gramacy, 2012), and hclust function (R Development Core Team, 2020).

Economic and sociocultural factors that best explain the ecosystem service bundles were analyzed using a distancebased redundancy analysis (db-RDA, Legendre and Andersson, 1999). This approach seeks the combinations of each variable in the explanatory matrix (stakeholder, benefit, and land tenure variables) that best explain the variation of the response matrix (ecosystem service bundles). This method is similar to RDA, but it allows dissimilarity measures for binary data. In this analysis, the distance matrix was obtained using the S14 similarity index of Gower and Legendre (1986). To determine the significance of explanatory variables in the relative importance of ecosystem service bundles a Monte Carlo permutation test (999 permutations) was run. The dependence between variables was also checked using the variance inflation factor (VIF) (Borcard et al., 2011), which measures to what extent each variable in the explanatory matrix is collinear with the others. Values over 10 indicate variables that are functionally related to one another. In that case, a method is justified to reduce the number of explanatory variables (Borcard et al., 2011). Analyses were performed by computing the distance binary matrix with the $\mathrm{R}$ ade4 package (Chessel et al., 2004), followed by the db-RDA of the vegan package (Oksanen et al., 2019).

To visualize the research progress of UA in LA, projections of all variables over the four sustainability domains (James, 2015) were made through wind rose diagrams built with the ggplot2 package (Wickham, 2017).

To identify issues and possible strategic directions in decisionmaking, information was organized considering the four basic components of a SWOT analysis (strengths, weaknesses, opportunities, and threats) in the environmental, societal, economic, and governance dimensions. Strengths were the achievements of UA; weaknesses were the problems or negative effects of the activity itself; opportunities were actions that enable the activity to be improved, transformed, or adapted in the urban socioecosystem; and threats were the external problems that could undermine the activity. Results and statements of authors in their studies were used, instead of the interviews by topics or to focus groups of stakeholders usually used in this methodology.

\section{RESULTS}

This search yielded a total of 182 reports. After removing duplicates and reports in which it was not possible to use proxy variables, a total of 147 were eligible among which 60 were written in English, 55 in Spanish, and 32 in Portuguese (Appendix 2). Since some of these included study cases from different countries, the final database gathered a total of 205 study cases of UA belonging to 18 LA countries. The search showed no results for El Salvador or for Panama. Most of the studies were primary research (59\%) with both quantitative and qualitative data (71\%). Information was collected mainly through interviews, documentary reviews, observations, surveys, workshops, and experimentation. Concepts and frameworks of
TABLE 1 | Urban ecosystem services, benefits, assets, and drivers identified in studies of UA in LA.

\begin{tabular}{|c|c|}
\hline \multicolumn{2}{|r|}{ Variables identified in studies of UA in LA } \\
\hline Urban ecosystem & Regulating services \\
\hline \multirow[t]{20}{*}{ services } & 1. Local climate and air quality regulation \\
\hline & 2. Water treatment \\
\hline & 3. Erosion and maintenance of soil fertility \\
\hline & 4. Moderation of extreme events \\
\hline & 5. Waste recycling \\
\hline & 6. Pollination \\
\hline & 7. Carbon sequestration and storage \\
\hline & Habitat and support services \\
\hline & 8. Habitat for species \\
\hline & 9. Maintenance of genetic diversity \\
\hline & Provisioning services \\
\hline & 10. Foods \\
\hline & 11. Aromatics and medicinal plants \\
\hline & 12. Flowers and ornamental plants \\
\hline & Cultural services \\
\hline & 13. Education \\
\hline & 14. Recreation (fairs, meetings, festivals, tourism) \\
\hline & $\begin{array}{l}\text { 15. Places and activities for vulnerable people (handicapped, } \\
\text { women, youngest, elderly, migrants, abandoned children, } \\
\text { social rehabilitation, health centers) }\end{array}$ \\
\hline & 16. Aesthetic, scenic beauty, and cultural heritage \\
\hline & 17. Traditional and popular knowledge \\
\hline \multirow[t]{6}{*}{ Benefits } & 18. Health (nutritional, mental, emotional) \\
\hline & 19. Food security \\
\hline & 20. Identity and social cohesion \\
\hline & 21. Expense reduction \\
\hline & 22. Employment \\
\hline & 23. Value chain (production, processing, transport, market) \\
\hline \multirow[t]{6}{*}{ Assets } & 24. Demographic information of urban farmers \\
\hline & 25. Training and technical support \\
\hline & 26. Academy engagement \\
\hline & 27. Incentive payments and credits \\
\hline & 28. Technology and infrastructure \\
\hline & 29. Institutional funds \\
\hline \multirow[t]{6}{*}{ Indirect drivers } & 30. Laws and environmental regulation \\
\hline & 31. Tenure and land use planning \\
\hline & 32. Self-/community-based organization \\
\hline & 33. Public government engagement \\
\hline & 34. NGOs, international agencies \\
\hline & 35. Private participation \\
\hline
\end{tabular}

ecosystem service assessment per se were not considered in the reviewed documents, but for this study, they were identified or deduced through proxy variables.

A total of 17 ecosystem services of UA were recognized: six benefits, six assets, and six indirect drivers (Table 1 and Appendix 1). Earthquakes and tsunami were the only direct natural drivers identified in two studies. Political context, economic crisis, armed conflicts, and both international and rural migrations were identified as the main indirect drivers at country scale. This study focused on the variables listed in Table $\mathbf{1}$. 


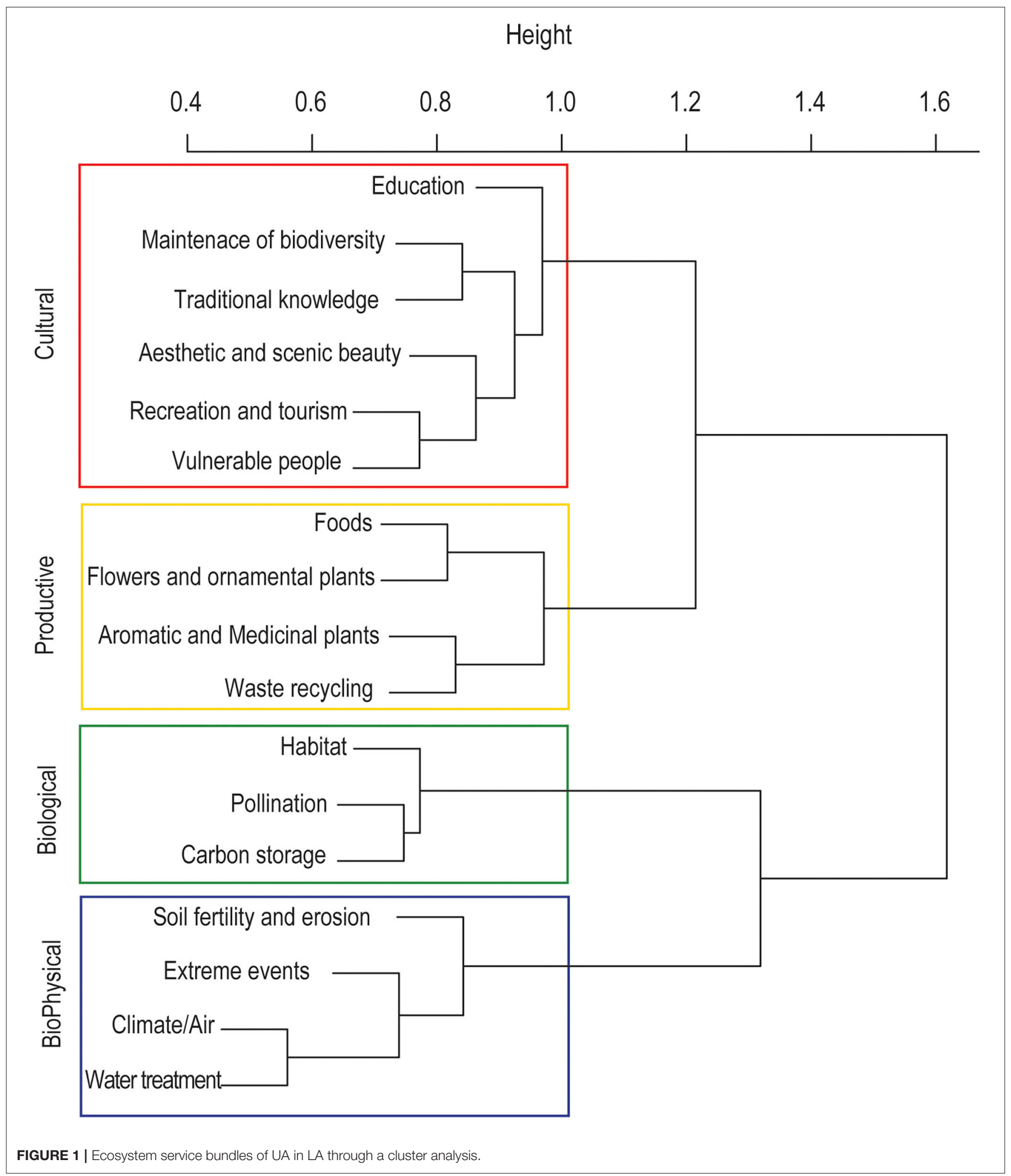

Cluster analysis identified four ecosystem service bundles (Figure 1). The first, the cultural bundle, included all cultural ecosystem services and one supporting service (maintenance of genetic biodiversity). The second, the productive bundle, gathered the provisioning services and one regulating service (waste recycling). The third, the biological bundle, included 


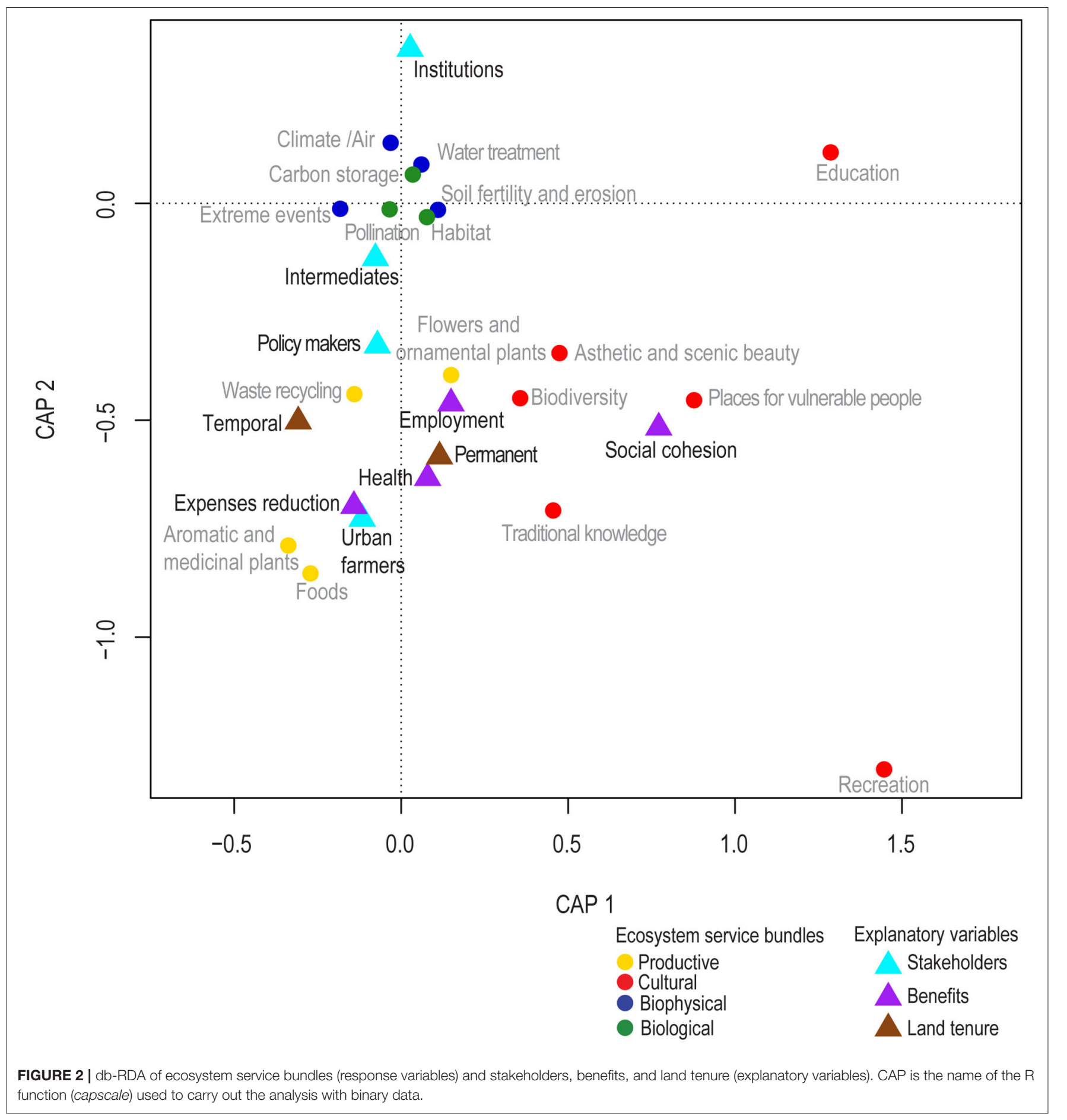

two regulating services (carbon sequestration and storage and pollination) and one supporting service (habitat for species). Finally, the biophysical bundle included only regulating services (soil fertility and erosion, extreme events, climate and air, and water treatment).

The db-RDA showed significant associations between the ecosystem service bundles and stakeholders, benefits, and land tenure variables ( $p=0.001$, from 999 permutations). This analysis explained $15 \%$ of total inertia, with $5 \%$ explained by the first axis (CAP1), and $4 \%$ by the second axis (CAP2, Figure 2). All variables showed VIF $<2$; it was therefore not necessary to apply a reduction method. The first axis (CAP1) revealed, on the one hand, that the studies focused on the association between urban farmers and the productive bundle, especially those that 


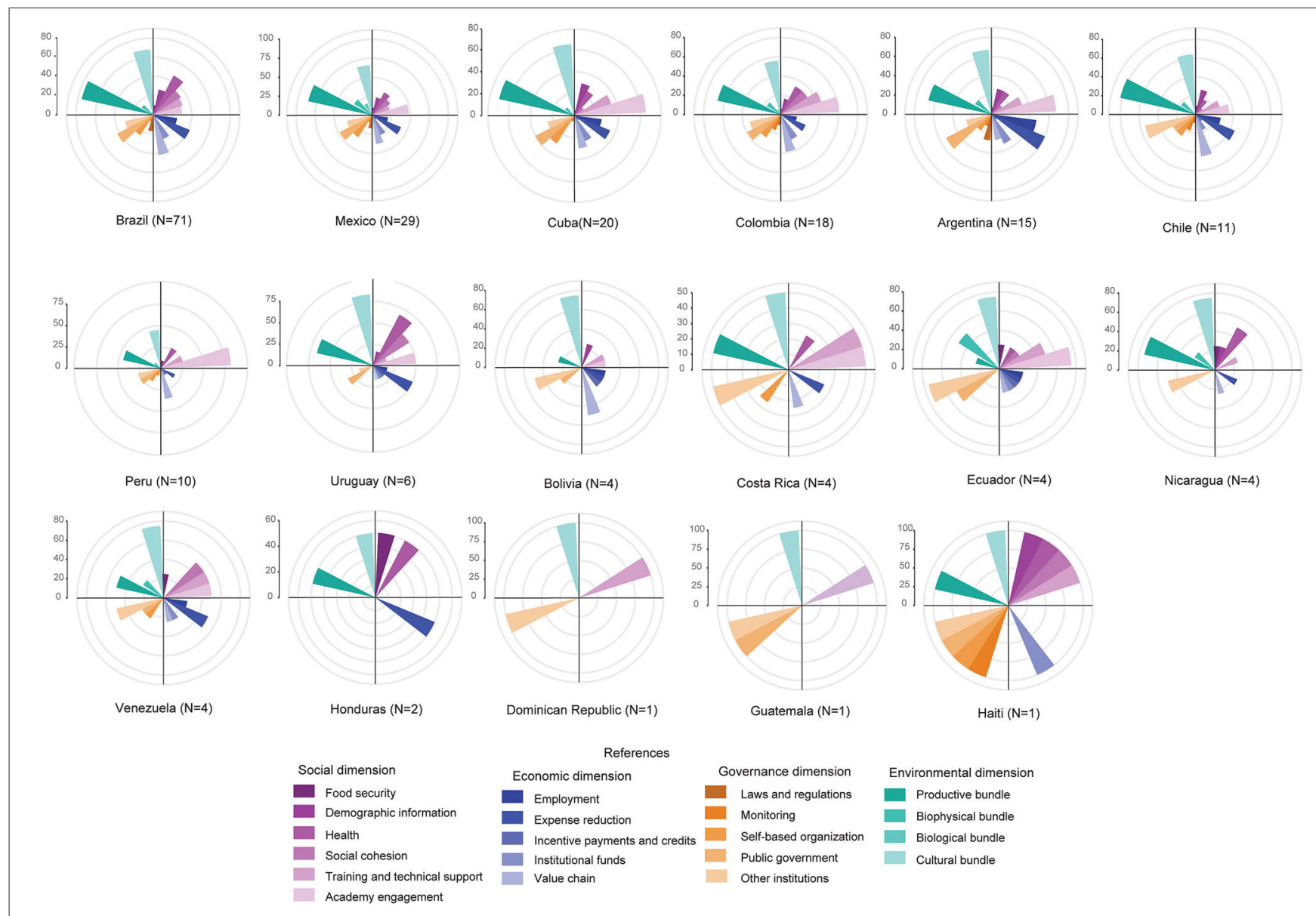

FIGURE 3 | Projections of ecosystem service bundles, benefits, stakeholders, and drivers over the four dimensions of sustainable development.

are part of their feeding, and that they benefit from an increase in their incomes due by reducing expenses. Policy makers and temporary land tenure were also associated with this group. On the other hand, most of the cultural bundle and the production of flowers and ornamental plants were associated with employment generation, social cohesion, and health benefits. The second axis (CAP2) revealed that the studies reviewed focused on the associations between urban farmers, policy makers, and both productive and cultural bundles. All the benefits obtained from these two bundles were in lands with either temporary or permanent tenure. Education and training support was the only cultural service associated with other institutions (academy, civil organizations, NGOs, or international agencies). All biophysical and biological bundles, as well as the intermediate stakeholders, were in the center of the figure, indicating their poor contribution to the explained inertia.

Projections of ecosystem service bundles, benefits, and drivers over the four dimensions of sustainable development were possible for 17 countries (Figure 3). In the case of Paraguay, the only record was part of a general review about hydroponics in LA. The environmental dimension showed a higher proportion of studies than the social, economic, and governance dimensions. Studies on the cultural and productive bundles were carried out most frequently in all countries, while studies on biophysical and biological bundles were absent or poorly studied in most countries. In the social dimension, urban farmers in most of the countries received some kind of training and technical support, and academic engagement was present in more than $70 \%$ of the countries. Health was the benefit most mentioned in the articles reviewed, followed by food security and social cohesion. Nevertheless, the relative frequency of their occurrence in studies within the countries was equal to or lower than $50 \%$. In the economic dimension, income improvement by reducing expenses and direct sales to final consumers, were the most frequent benefits mentioned by urban farmers, while incentive payments and credits were the least frequent. In the governance dimension, studies mentioning the involvement of the government (local, regional, or national) and other institutions were the most frequent in most countries, while the existence of legal regulations, the monitoring of UA activities, and self-based organization were poorly mentioned or studied.

UA in LA countries showed most of its strengths related to the variety of ecosystem services as well as the benefits and beneficiaries involved in the different activities (Table 2). The main weaknesses were related to the misuse of inputs (e.g., 
TABLE 2 | Strengths, weaknesses, opportunities, and threats of UA in LA.

\begin{tabular}{|c|c|c|}
\hline \multirow[t]{7}{*}{ Internal } & Strengths & Weaknesses \\
\hline & S1. Provision of multiple services and benefits ${ }^{\star}$ & W1. Social and environmental exposition to agrochemical inputs \\
\hline & S2. Direct accessibility to green fresh products or through short value chains & $\begin{array}{l}\text { W2. Use of water pipelines, illegal connections, lack of shortage } \\
\text { dry periods }\end{array}$ \\
\hline & S3. Versatile activity in economic, social, spatial, and technical aspects & $\begin{array}{l}\text { W3. Negative effects on health due to the use of untreated wate } \\
\text { or through atmospheric or soil pollution }\end{array}$ \\
\hline & S4. Gender equity and social group empowerment & $\begin{array}{l}\text { W4. Poor quantitative assessment on food security and human } \\
\text { and environmental health }\end{array}$ \\
\hline & & $\begin{array}{l}\text { W5. Pathogens and diseases associated with vegetables and } \\
\text { farming activity }\end{array}$ \\
\hline & & W6. Gender inequality \\
\hline \multirow[t]{14}{*}{ External } & Opportunities & Threats \\
\hline & $\begin{array}{l}\text { 01. Development of organoponics, hydroponics, new crop varieties, } \\
\text { technology for indoor cultivation of vegetables }\end{array}$ & T1. Water, atmospheric, and soil pollution \\
\hline & O2. Development of new markets (e.g., organic and biodynamic) & T2. Land tenure: illegal use or settlement \\
\hline & $\begin{array}{l}\text { O3. Production of agronomic inputs: seedlings, containers, biological } \\
\text { control, biopesticides, bio-fertilizers, vermiculture, waste recycling, } \\
\text { substrates, soilless cultivation systems }\end{array}$ & T3. Lack of laws and regulation of UA \\
\hline & $\begin{array}{l}\text { O4. Green-gray hybrid infrastructures: green rooftops, green walls, } \\
\text { greenhouses, green architecture }\end{array}$ & T4. Lack of public policies to include UA in territorial planning \\
\hline & O5. NBS: micro-farming on steep slopes as landslide risk mitigation & $\begin{array}{l}\text { T5. Failure of UA programs due to lack of continuity of public } \\
\text { policies in the long and middle terms }\end{array}$ \\
\hline & $\begin{array}{l}\text { O6. Water-related products: water shortage, irrigation systems, filters, water } \\
\text { treatment, water recycling, rain-harvesting systems }\end{array}$ & T6. Citizen insecurity leads to robberies in the gardens \\
\hline & $\begin{array}{l}\text { 07. New careers: urban farmers, careers in the food sector (e.g., provider } \\
\text { for restaurants or institutions and food processing and conservation) }\end{array}$ & T7. Real estate business and urban expansion \\
\hline & 08. Corporate image, social responsibility, branding & T8. Long value chains \\
\hline & $\begin{array}{l}\text { O9. Real estate business including vegetable plots, gardens, and } \\
\text { green-gray infrastructure }\end{array}$ & \\
\hline & $\begin{array}{l}\text { 010. Green digital business: app development to connect urban farmers } \\
\text { and other activities derived from UA }\end{array}$ & \\
\hline & 011. Education, farming schools, and training courses & \\
\hline & O12. Touristic development & \\
\hline & $\begin{array}{l}\text { 013. Use of UA in the health sector: products and activities with healing, } \\
\text { emotional, and therapeutic issues }\end{array}$ & \\
\hline
\end{tabular}

${ }^{\star}$ Ecosystems services and benefits listed.

water, fertilizers, and pesticides) and negative effects on human and environmental health due to exposure to physical and biological agents. Gender inequality was both a strength and a weakness, depending on the cultural context in which UA is carried out. Regarding externalities, the studies showed that UA in LA countries was a field full of opportunities related to the four dimensions of sustainability considered in this study. Most of the threats were related to regulation and governance and to land tenure and use. Real estate businesses were both opportunities and threats.

\section{DISCUSSION}

The production of fresh green foods to improve food security and the health conditions of the poorest urban dwellers has been regarded as a primary objective in the GS (Orsini et al., 2013; Gray et al., 2020). In agreement with this, the results of this study showed that most of the Research Topics in LA countries focused on the production of urban green foods within the productive bundle. Nevertheless, the cultural bundle was seen to be of similar importance. Urban farmers recognized UA as an activity with important services that enabled vulnerable people to improve their lives and well-being (Cantor, 2010; Costa et al., 2015; Batitucci et al., 2019), and allow sharing popular and traditional knowledge (Montes and Gómez, 2011; Gold, 2014; Fernández et al., 2020), enjoying aesthetic or scenic beauty (Lattuca and Terrile, 2014; Urbana et al., 2019), promoting tourism (Losada et al., 2000; Lattuca and Terrile, 2014), to organizing fairs (Niederle et al., 2018; Peralta-González et al., 2019), and educational and recreational activities (Urbana et al., 2019; Nagib and Nakamura, 2020), or recognizing that UA promotes the maintenance of urban biodiversity (Pino et al., 2007; do Amaral and Guarim Neto, 2008; Alomía-Lucero et al., 2020). 
This multifunctional nature of UA and the places where it is carried out are opportunities to integrate the activity within planning perspectives consistent with urban sustainability (Delpino-Chamy et al., 2019; Gomes et al., 2019). As a counterpart of the focus laid on the productive and cultural bundles, the biophysical and biological bundles have been neglected in most of the LA countries. Even though they underlie all the expressions of UA and can reduce the risks associated with contamination, degradation, or waste, there are few studies of UA related to water shortage and quality (Lugo-Morin, 2010; Ebel et al., 2020), soil fertility (Alban et al., 2017; Ebel, 2020), air quality (Vega Castro and Salamanca Rivera, 2015), carbon emissions and shortage (Cerón-Palma et al., 2013), or the emergence of pests and diseases (Paviotti-Fischer et al., 2019; Ebel, 2020). The focus of policy makers and institutions on the productive bundle in most research in LA countries supports the interpretation that the GS has made efforts to solve desperate conditions in the short term (Gray et al., 2020), apparently unaware that the biophysical, biological, and cultural bundles have key roles in maintaining UA in the middle and long terms, as well as in reducing the environmental, social, and economic risks.

In the social dimension, academic and other institutions together with governments have also played an important role in supporting UA, through training courses and educational activities in most LA countries. Nevertheless, it is difficult to assess the effectiveness of UA in improving the health, food security, and social cohesion of low-income residents. Some studies, for example, have reported on dietary changes and infant mortality reductions in the city (FAO, 2014), on the nutritional contribution of UA (Orsini et al., 2010; Pescio, 2020), or on the risks associated with exposure to agrochemicals (Olivares Reumont, 2013; Eandi et al., 2021). But in most of the studies, health topics have been dealt with in terms of the qualitative perception of urban dwellers or other social actors (Ribeiro et al., 2015) rather than quantitatively assessed; food security has been used discursively (Muñoz-Rodríguez et al., 2020); and social cohesion has not been systematized or has been poorly studied even though it is closely related to the cultural bundle. Demographic information is a very important asset for managers and decision-makers, but in most of the studies, it was an infrequent Research Topic and most of the data have been limited to information on age and gender.

Within the economic dimension, consistently with other studies from the GS (De Bon et al., 2009; Zezza and Tasciotti, 2010), the contribution of UA production to the livelihoods of urban farmers and their reduction of expenses were the main benefits assessed by urban farmers. Even though employment generation appears in second place, there are gaps in the value chain because; most of the activities still take place in the informal sector, and the dynamics of local economies are poorly known. Thus, employment generation is a benefit that may have been underestimated and is a topic that should be part of future research agendas. Incentive payments and credits have also been neglected, but some successful cases, such as the use of private sleeping lands for urban farmers in return for tax reductions to the land owners, and material and technical support to urban farmers from the local government and other institutions
(Bellenda et al., 2018; Oliveira et al., 2019; Oliveira and de Santos, 2020), or implementation of micro-credit programs for poorer families and communities to carry out UA activities (Yagüe et al., 2013; Dieleman, 2017), are useful tools for increasing their, and particularly women's, economic wellbeing and empowerment (Hishigsuren, 2007).

In relation to the governance dimension, the results of this study indicate that the efforts made by some of the LA governments with national and international institutions to improve the nutritional status of the poorest urban dwellers suffered from the lack of legal frameworks to support the UA activities as well as a lack of monitoring for making adjustments to the different programs. These findings challenge the efficacy, usefulness, and prevalence of UA in LA countries, reinforcing the idea that UA should be incorporated into public policies, promoted, and regulated by adequate legal frameworks in all its dimensions, and understood by decision-makers, who should be informed of the functioning of existing programs through formal and informal feedback (Avila-Sanchez, 2019; Muñoz-Rodríguez et al., 2020). The governance of UA should also incorporate the community-based organizations of urban farmers who are the practitioners of the activity and the final decision-makers.

The SWOT matrix showed that UA in LA provides many opportunities to offset weaknesses, build strengths, and convert threats into opportunities. Its multifunctional strengths are the additional ecosystem services, benefits, and assets beyond food production, which have been under-researched academically or scarcely integrated into policy and planning. Similarly, most of the weaknesses have derived from a lack of studies on the misuse, degradation, loss of ES, or poor knowledge of ecosystem dis-services. UA in LA has promoted the emergence of opportunities (Gianquinto et al., 2007; Schiavo, 2009; RodríguezDelfín, 2012; Pérez Fernández et al., 2018; Alomía-Lucero et al., 2020; Fuzinatto et al., 2021) to integrate popular knowledge and to develop new products, technologies, careers, jobs, and businesses, often supported by the urban farmers themselves, by international agencies, and sometimes by universities and scientific institutions. Despite the threats and difficulties that UA experiences in LA, there are also cases in the region (FAO, 2014; Lattuca and Terrile, 2014; Amato-Lourenço et al., 2021) that are examples of how local governments, through public policies in urban planning and legal frameworks, together with civil organizations and other institutions, have managed to incorporate UA into the urban dynamics, improving the wellbeing of the participants, and sustaining the programs over time.

\section{CONCLUSIONS}

UA in LA is not a new issue; what has changed is its significance in the global and regional arenas. Although UA literature in the region is abundant, it is mainly found in non-scientific sources, such as technical reports, bulletins, or projects (Wadumestrige Dona et al., 2021), thus being in the public domain but effectively unavailable to the broader community. This study synthesized the scientific information on UA in the LA region over the past 21 years, using one global and two regional bibliographic 
search platforms. The use of concepts and frameworks from ecosystem services and SWOT analysis revealed the state of the art of UA in the LA region, its gaps, and factors affecting the activity in cities. Both approaches may be effective tools for making scientific information available to managers and formulating strategies for decision makers. The results highlight UA in the LA as a multifunctional activity that needs to be assessed from a multidimensional approach and that indirect drivers, summarized in the governance, other institutions, and land tenure, and the urban farmers themselves may play a central role in sustaining this green urban activity.

\section{DATA AVAILABILITY STATEMENT}

The original contributions presented in the study are included in the article/Supplementary Material, further inquiries can be directed to the corresponding author.

\section{REFERENCES}

Abu Hatab, A., Cavinato, M. E. R., Lindemer, A., and Lagerkvist, C. J. (2019). Urban sprawl, food security and agricultural systems in developing countries: a systematic review of the literature. Cities 94, 129-142. doi: 10.1016/j.cities.2019.06.001

Alban, R. E., Arteaga, M. I., and Herrera, F. F. (2017). Urban agriculture in caracas: diagnosis of agro-productive spaces from a socio-ecological perspective | La agricultura urbana en caracas: diagnóstico de los espacios agroproductivos desde una perspectiva socioecológica. Cuad. Desarro. Rural 14, 1-19. doi: 10.11144/Javeriana.cdr14-80.aucd

Alomía-Lucero, J., Castro-Bedriñana, J., and Chirinos-Peinado, D. (2020). Rooftop urban agriculture model with two tomato varieties (Lycopersicum esculentum Mill) and toppings in the high jungle - Peru. Adv. Sci. Technol. Eng. Syst. 5, 446-450. doi: 10.25046/aj050157

Amato-Lourenço, L. F., Buralli, R. J., Ranieri, G. R., Hearn, A. H., Williams, C., and Mauad, T. (2021). Building knowledge in urban agriculture: the challenges of local food production in São Paulo and Melbourne. Environ. Dev. Sustain. 23, 2785-2796. doi: 10.1007/s10668-020-00636-x

Avila-Sanchez, H. (2019). Agricultura Urbana y Periurbana. Reconfiguraciones territoriales y potencialidades en torno a los sistemas alimentarios urbanos. Investig. Geográficas, 98. doi: 10.14350/rig.59785

Batitucci, T. D. O., Cortines, E., Almeida, F. S., and De Almeida, Â. A. (2019). Agriculture in urban ecosystems: a step to cities sustainability. Ambient. e Soc. 22, 3. doi: 10.1590/1809-4422asoc0277r3vu19l4ao

Bellenda, B., Galván, G., García, M., Gazzano, I., Gepp, V., Linari, G., et al. (2018). Agricultura urbana agroecológica: más de una década de trabajo de Facultad de Agronomía (Udelar) junto a diversos colectivos sociales. Agric. Urbana Agroecol. Década Trab. Fac. Agron. Junto Divers. Colect. Soc. 22, 140-151. doi: 10.31285/agro.22.1.15

Borcard, D., Gillet, F., and Legendre, P. (2011). Numerical Ecology With R, Cham: Springer International Publishing AG. doi: 10.1007/978-1-4419-7976-6

Cantor, K. M. (2010). Agricultura urbana: Elementos valorativos sobre su sostenibilidad. Cuad. Desarro. Rural 7, 59-84. doi: 10.11144/Javeriana.cdr7-65.auev

Cerón-Palma, I., Sanyé-Mengual, E., Oliver-Solà, J., Montero, J.-I., PonceCaballero, C., and Rieradevall, J. (2013). Towards a green sustainable strategy for social neighbourhoods in Latin America: Case from social housing in Merida, Yucatan, Mexico. Habitat Int. 38, 47-56. doi: 10.1016/j.habitatint.2012.09.008

Chessel, D., Dufour, A.-B., and Thioulouse, J. (2004). The ade4 package-I- Onetable methods. R News 4, 5-10. Available online at: https://cran.r-project.org/ doc/Rnews/ (accessed August 05, 2021).

\section{AUTHOR CONTRIBUTIONS}

The author confirms being the sole contributor of this work and has approved it for publication.

\section{ACKNOWLEDGMENTS}

The author would like to thank the two reviewers for their valuable comments in order to improve this article and also C. Marty for reviewing the text, the editorial, and the Frontiers Fee Support Program for the publication of this article.

\section{SUPPLEMENTARY MATERIAL}

The Supplementary Material for this article can be found online at: https://www.frontiersin.org/articles/10.3389/frsc.2021. 792616/full\#supplementary-material

Costa, C. G. A., Garcia, M. T., Ribeiro, S. M., Salandini, M. F. S., and Bógus, C. M. (2015). Community vegetable gardens as a health promotion activity: an experience in Primary Healthcare Units. Hortas comunitárias como atividade promotora de saúde: Uma experiência em Unidades Básicas de Saúde. Cienc. e Saude Coletiva 20, 3099-3110. doi: 10.1590/1413-812320152010.00352015

Daw, T., Brown, K., Rosendo, S., and Pomeroy, R. (2011). Applying the ecosystem services concept to poverty alleviation: the need to disaggregate human wellbeing. Environ. Conserv. 38, 370-379. doi: 10.1017/S0376892911000506

De Bon, H., Parrot, L., and Moustier, P. (2009). Sustainable urban agriculture in developing countries: a review. Sustain. Agric. 30, 619-633. doi: 10.1007/978-90-481-2666-8_38

De Zeeuw, H., Van Veenhuizen, R., and Dubbeling, M. (2011). The role of urban agriculture in building resilient cities in developing countries. J. Agric. Sci. 149, 153-163. doi: 10.1017/S0021859610001279

Delpino-Chamy, M., Alarcon, M., Fernández, S., and Soto, J. (2019). Methodology to identify and assess AG roecological practices in metropo litan areas. Case study, concepción, Chile. Int. J. Des. Nat. Ecodynamics 14, 119-130. doi: 10.2495/DNE-V14-N2-119-130

Díaz, S., Demissew, S., Joly, C., Lonsdale, W. M., and Larigauderie, A. (2015). A Rosetta stone for nature's benefits to people. PLoS Biol. 13, e1002040. doi: 10.1371/journal.pbio.1002040

Dieleman, H. (2017). Urban agriculture in Mexico City; balancing between ecological, economic, social and symbolic value. J. Clean. Prod. 163, S156-S163. doi: 10.1016/j.jclepro.2016.01.082

do Amaral, C. N., and Guarim Neto, G. (2008). Os quintais como espaços de conservação e cultivo de alimentos: um estudo na cidade de Rosário Oeste (Mato Grosso, Brasil). Bol. do Mus. Para. Emílio Goeldi. Ciências Humanas 3, 329-341. doi: 10.1590/S1981-81222008000300004

Dumat, C., Pierart, A., Shahid, M., and Khalid, S. (2019). "Pollutants in urban agriculture," in Bioremediation of Agricultural Soils ed SanchezHernandez J. C. (Boca Raton, FL: CRC Press), 61-84. doi: 10.1201/978131520 5137-4

Eandi, M. A., Dezzotti, L., and Butinof, M. (2021). Health care and exposure to pesticides in periurban horticulture: the case of the green belt of the city of Cordoba, Argentina. Cienc. e Saude Coletiva 26, 1575-1584. doi: 10.1590/1413-81232021264.27922018

Ebel, R. (2020). Chinampas: An urban farming model of the aztecs and a potential solution for modern megalopolis. Horttechnology 30, 13-19. doi: 10.21273/HORTTECH04310-19

Ebel, R., Fallahi, E., Griffis, J. L., Nandwani, D., Nolan, D., Penhallegon, R. H., et al. (2020). Urban horticulture, from local initiatives to global success stories. Horttechnology 30, 4-5. doi: 10.21273/HORTTECH04525-19

FAO (2014). Growing Greener Cities in Latin America and the. 
Fernández, K. G., Moreno-Calles, A. I., Casas, A., and Blancas, J. (2020). Contributions of urban collective gardens to local sustainability in Mexico City. Sustainability. 12, 1-23. doi: 10.3390/su12187562

Follmann, A., Willkomm, M., and Dannenberg, P. (2021). As the city grows, what do farmers do? A systematic review of urban and peri-urban agriculture under rapid urban growth across the Global South. Landsc. Urban Plan. 215, 104186. doi: 10.1016/j.landurbplan.2021.104186

Fuzinatto, N. M., Danielli, J. A., Preschlak, D., and Fischer, A. (2021). Financial feasibility of organic strawberry production for the local market. Análise de viabilidade financeira da produção orgânica de morangos para comercialização local. Rev. em Agronegocio e Meio Ambient. 14, e006916. doi: 10.17765/2176-9168.2021v14n1e006916

Gianquinto, G., Orsini, F., Michelon, N., Da Silva, D. F., and De Faria, F. D. (2007). Improving yield of vegetables by using soilless micro-garden technologies in peri-urban area of north-east Brazil. Acta Hortic. 747, 57-65. doi: 10.17660/ActaHortic.2007.747.4

Gold, M. (2014). Peasant, patriot, environmentalist: sustainable development discourse in Havana. Bull. Lat. Am. Res. 33, 405-418. doi: 10.1111/blar.12175

Gomes, J. F. B., Gomes, R. S. B., and Souza, A. O. (2019). The multifunctionality of urban horticulture and its integration with the city ecosystem: a brief review of concepts and the case of São Luís. A multifuncionalidade da horticultura urbana e sua integração ao ecossistema das cidades: Uma breve revisão de. Hortic. Bras. 37, 252-259. doi: 10.1590/s0102-053620190301

Gower, J. C., and Legendre, P. (1986). Metric and Euclidean properties of dissimilarity coefficients. J. Classif. 3, 5-48. doi: 10.1007/BF01896809

Gray, L., Elgert, L., and WinklerPrins, A. (2020). Theorizing urban agriculture: north-south convergence. Agric. Human Values 37, 869-883. doi: 10.1007/s10460-020-10015-x

Hearn, A. H., Mauad, T., Williams, C., Amato-Lourenço, L. F., and Reis Ranieri, G. (2020). Digging up the past: urban agriculture narratives in Melbourne and São Paulo. J. Urban. 14, 1828144. doi: 10.1080/17549175.2020.1828144

Hishigsuren, G. (2007). Evaluating mission drift microfinance: lessons for programs with social mision. Eval. Rev. 31, 23. doi: 10.1177/0193841X06297886

James, P. (2015). Urban Sustainability in Theory and Practice. Circles of Sustainability. New York: Routledge Taylor and Francis Group, 282. doi: 10.4324/9781315765747

Kelley, L. A., Gardner, S. P., and Surcliffe, M. J. (1996). An automated approach for clustering an ensemble of nmrderivedprotein structures into conformationally related subfamilies. Protein Eng. Des. Sel. 9, 1063-1065. doi: 10.1093/protein/9.11.1063

King, M. F., Ren,ó, V. F., and Novo, E. M. L. M. (2014). The concept, dimensions and methods of assessment of human well-being within a socioecological context: a literature review. Soc. Indic. Res. 116, 681-698. doi: $10.1007 /$ s11205-013-0320-0

Lattuca, A., and Terrile, R. (2014). El Programa de Agricultura Urbana de la Municipalidad de Rosario, Argentina. Hábitat Soc. 7, 95-104. doi: 10.12795/HabitatySociedad.2013.i6.06

Legendre, P., and Andersson, M. J. (1999). Distance-based redundancy analysis: Testing multispecies responses in multifactorial ecological experiments. Ecol. Monogr. 69, 1-24. doi: 10.1890/0012-9615(1999)069[0001:DBRATM]2. $0 . \mathrm{CO} ; 2$

Losada, H., Bennett, R., Soriano, R., Vieyra, J., and Cortés, J. (2000). Urban agriculture in Mexico City: functions provided by the use of space for dairy based livelihoods. Cities 17, 419-431. doi: 10.1016/S0264-2751(00)00041-X

Lugo-Morin, D. R. (2010). Residual agriculture: some implications for its discussion. Ciencia Sociedad. 35, 657-680. Available online at: https://www. redalyc.org/articulo.oa?id=87020011006 (accessed April 14, 2021).

MA (2003). Ecosystems and Human Well-being: A Framework for Assessment. Washington, DC. Island Press.

MA (2005). Ecosystems and Human Well-being: Synthesis. Washington, DC. Island Press.

Miguel, S. (2011). Journals and scientific production in Latin America and the Caribbean: its visibility in SciELO, RedALyC and SCOPUS. Rev. Inte. Bibliotecol. 34, 187-199. Available online at: https://www.redalyc.org/articulo. oa?id=179022554006 (accessed February 13, 2021).

Montes, R. C., and Gómez, G. A. (2011). Valuation of sechium edule as an alimentary alternative and recuperation of bonds to the country. Biotecnol. Sect. Agropecu. Agroind. 9, 198-209. Available online at: http://www.scielo.org.co/
scielo.php?script=sci_abstract\&pid=S1692-35612011000200022 (accessed May 04, 2021).

Mougeot, L. J. A. (2005). Agropolis: The Social, Political, and Environmental Dimensions of Urban Agriculture. London: Earthscan.

Muñoz-Rodríguez, M., Fernández-González, C., Aguilar-Gallegos, N., and González-Santiago, M. V. (2020). The primacy of politics in public food security policies: The case of home gardens. Sustainability. 12, 4316. doi: $10.3390 /$ su12104316

Nagib, G., and Nakamura, A. C. (2020). Urban agriculture in the city of São Paulo: New spatial transformations and ongoing challenges to guarantee the production and consumption of healthy food. Glob. Food Sec. 26, 100378. doi: 10.1016/j.gfs.2020.100378

Niederle, P. A., Schneider, T. C., and Schubert, M. N. (2018). Comida relacional : produção de sentidos e sociabilidades nas práticas alimentares da quinta da videira. Rev. Theomi. 38, 138-149. Available online at: https://www.redalyc.org/articulo.oa?id=12455418011 (accessed April $14,2021)$.

Oksanen, J., Blanchet, F. G., Kindt, R., Legendre, P., and Minchin, P. R., O’hara, R. B., et al. (2019). Vegan: Community Ecology Package. Available online at: http:// vegan.r-forge.r-project.org/ (accessed August 02, 2021).

Olivares Reumont, S. (2013). Niveles de cadmio, plomo, cobre y zinc en hortalizas cultivadas en una zona altamente urbanizada de la ciudad de la habana, Cuba. Rev. Int. Contam. Ambient. 29, 285-293. Available online at: http://www.scielo.org.mx/scielo.php?script=sci_arttext\&pid=S018849992013000400006 (accessed May 04, 2021).

Oliveira, A. C. N., and de Santos, E. V. M. (2020). A importância da agricultura urbana: um estudo sobre o programa Eco Hortas Comunitárias no município de Campos dos Goytacazes - RJ. Rev. Cerrados 16, 51-68. doi: $10.22238 / \mathrm{rc} 24482692201816025168$

Oliveira, E. A. A. Q., Nunes, L. L. M., and Moraes, M. B., de (2019). Características Socioeconômica e ambiental da Agricultura Urbana em Imperatriz-MA. Redes 24, 241-271. doi: 10.17058/redes.v24i3.14105

Opitz, I., Berges, R., Piorr, A., and Krikser, T. (2016). Contributing to food security in urban areas: differences between urban agriculture and periurban agriculture in the Global North. Agric. Human Values 33, 341-358. doi: 10.1007/s10460-015-9610-2

Orsini, F., Kahane, R., Nono-Womdim, R., and Gianquinto, G. (2013). Urban agriculture in the developing world: a review. Agron. Sustain. Dev. 33, 695-720. doi: 10.1007/s13593-013-0143-z

Orsini, F., Morbello, M., Fecondini, M., and Gianquinto, G. (2010). Hydroponic gardens: Undertaking malnutrition and poverty through vegetable production in the suburbs of lima, Peru. Acta Horticult. 881, 173-177. doi: 10.17660/ActaHortic.2010.881.21

Paviotti-Fischer, E., Lopes-Torres, E. J., Santos, M. A. J., Brandolini, S. V. P. B., and Pinheiro, J. (2019). Xiphidiocercariae from naturally infected Lymnaea columella (Mollusca, gastropoda) in urban area: morphology and ultrastructure of the larvae and histological changes in the mollusc host. Brazilian J. Biol. 79, 446-451. doi: 10.1590/1519-6984.182501

Peralta-González, C. A., Mondragón-Ríos, R., and Bello-Baltazar, E. (2019). Espacios socioculturales y mecanismos de comunicación para el aprendizaje y apropiación de conocimientos sobre el uso de plantas medicinales y gastronómicas en San Cristóbal de Las Casas, Chiapas. Estud. Soc. Rev. Aliment. Contemp. y Desarro. Reg. 29, 613. doi: 10.24836/es.v29i53.613

Pérez Fernández, A. R., Ruiz Morales, M., Lobato Calleros, M. O., Valera, E. P., and Rodríguez Salinas, P. (2018). Sustrato Biofísico Para Agricultura Protegida Y Urbana A Partir De Compost Y Agregados Provenientes De Los Residuos Sólidos Urbanos. Rev. Int. Contam. Ambient. 34, 383-394. doi: 10.20937/RICA.2018.34.03.02

Pescio, F. J. (2020). Balance between the production of an agroecological orchard and the nutritional demand of an average household in the Metropolitan Area of Buenos Aires | Balance entre la producción de una huerta agroecológica y la demanda nutricional de una familia tipo. Rev. Investig. Agropecu. 46, 116-122. Available online at: http://www.scielo.org.ar/scielo.php?script=sci_abstract\& pid=S1669-23142020000100116 (accessed April 06, 2021).

Pino, M., de los, A., Hernández, L., Domin,í, M. E., Ramírez, A., Terán, Z., et al. (2007). Cultivos tropicales revista cuatrimestral. Cultiv. Trop. 28, 13-19. Available online at: http://www.redalyc.org/articulo.oa?id=193217731002 (accessed April 14, 2021). 
Potschin-Young, M., Haines-Young, R., Görg, C., Heink, U., Jax, K., and Schleyer, C. (2018). Understanding the role of conceptual frameworks: Reading the ecosystem service cascade. Ecosyst. Serv. 29, 428-440. doi: 10.1016/j.ecoser.2017.05.015

Pudup, M. B. (2008). It takes a garden: cultivating citizen-subjects in organized garden projects. Geoforum 39, 1228-1240. doi: 10.1016/j.geoforum.2007.06.012

R Development Core Team (2020). R: A Language and Environment for Statistical Computing. Vienna: R Foundation for Statistical Computing. Available online at: http://www.R-project.org (accessed August 2, 2021).

Ribeiro, S. M., Bógus, C. M., and Watanabe, H. A. W. (2015). Agroecological urban agriculture from the perspective of health promotion. Agricultura urbana agroecológica na perspectiva da promoção da saúde. Saude Soc. 24, 730-743. doi: $10.1590 /$ S0104-12902015000200026

Rodríguez-Delfín, A. (2012). Advances of hydroponics in Latin America. Acta Horticult. 947, 23-32. doi: 10.17660/ActaHortic.2012.947.1

Romero-Duque, L. P., Trilleras, J. M., Castellarini, F., and Quijas, S. (2020). Ecosystem services in urban ecological infrastructure of Latin America and the Caribbean: How do they contribute to urban planning? Sci. Total Environ. 728, 138780. doi: 10.1016/j.scitotenv.2020.138780

Sanyé-Mengual, E. (2015). Sustainability assessment of urban rooftop farming using an interdisciplinary approach (Doctoral Thesis dissertation). Bellaterra: ICTA, Universitat Autonoma de Barcelona.

Schiavo, C. (2009). Empoderamiento y acción colectiva en producciones agroalimentarias con identidad territorial. PAMPA 1, 9-50. doi: 10.14409/pampa.vli5.3162

Smit, J., Nasr, J., and Ratta, A. (2001). "Urban agriculture yesterday and today (Chap 2)," in Urban Agriculture: Foods Jobs and Sustainable Cities, eds J. Smit, J. Nasr, and A. Ratta (Washington, DC: The Urban Agriculture Network, Inc.), 31.

TEEB-The Economics of Ecosystems and Biodiversity (2011). TEEB Manual for Cities: Ecosystem Services in Urban Management. Available online at: www.teebweb.org (accessed October 1, 2019).

Temple, L., and Moustier, P. (2004). Les fonctions et contraintes de l'agriculture périurbaine de quelques villes africaines (Yaoundé, Cotonou, Dakar). Cah. Agric. 13, 15-22. Available online at: http://publications.cirad.fr/une_notice. php?dk=519694 (accessed October 05, 2021).

United Nations (2019). World Population Prospects 2019. Available online at: http://www.ncbi.nlm.nih.gov/pubmed/12283219 (accessed May 6, 2021).

United Nations Development Programme (2013). Green Jobs for Women and Youth: What Can Local Governments Do? Available online at: http:// www.undp.org/content/undp/en/home/librarypage/poverty-reduction/ participatory_localdevelopment/green-jobs-for-women-and-youth--whatcan-local-governaments-do-/ (accessed April 5, 2021).
Urbana, A., Vanesa Molina Posada, D., Natalia Molina Jaramillo, A., and Adriana Muñoz-Duque, L. (2019). Agricultura urbana. Revista virtual? 'Cómo citar este artículo? Available online at: http://www.ucn.edu.co/.

van Veenhuizen, R. (2006). Cities Farming for the Future. Urban Agriculture for Green and Productive Cities. (Philippines: IIRR and ETC Urban Agriculture), 474

Vega Castro, D. A., and Salamanca Rivera, Á. P. (2015). Contenidos de plomo en acelga común Beta vulgaris L., producida en le contexto de la agricultura urbana (Bogotá, Colombia). Luna Azul 40, 44-53. doi: 10.17151/luaz.20 16.42 .5

Wadumestrige Dona, C. G., Mohan, G., and Fukushi, K. (2021). Promoting urban agriculture and its opportunities and challenges-a global review. Sustainability. 13, 9609. doi: 10.3390/su13179609

White, D., and Gramacy, R. B. (2012). Mapping, Prunning, and Graphing Tree Models. Available online at: http://cran.nexr.com/web/packages/maptree/ index.html (accessed July 29, 2021).

Wickham, H. (2017). ggplot2: Elegant Graphics for Data Analysis. New York, NY: Springer Verlag.

Yagüe, J. L., Montes, A., and Morales, F. J. (2013). Evaluation of development projects: a process-centered approach in the Outskirts of Lima, Peru. Cuad. Desarro. Rural 10, 181-200. Available online at: https://www.redalyc.org/ articulo.oa?id=11726378003 (accessed April 14, 2021).

Zezza, A., and Tasciotti, L. (2010). Urban agriculture, poverty, and food security: Empirical evidence from a sample of developing countries. Food Policy 35, 265-273. doi: 10.1016/j.foodpol.2010.04.007

Conflict of Interest: The author declares that the research was conducted in the absence of any commercial or financial relationships that could be construed as a potential conflict of interest.

Publisher's Note: All claims expressed in this article are solely those of the authors and do not necessarily represent those of their affiliated organizations, or those of the publisher, the editors and the reviewers. Any product that may be evaluated in this article, or claim that may be made by its manufacturer, is not guaranteed or endorsed by the publisher.

Copyright (c) 2022 Castellarini. This is an open-access article distributed under the terms of the Creative Commons Attribution License (CC BY). The use, distribution or reproduction in other forums is permitted, provided the original author(s) and the copyright owner(s) are credited and that the original publication in this journal is cited, in accordance with accepted academic practice. No use, distribution or reproduction is permitted which does not comply with these terms. 